\section{Nature of classroom environment and achievement in integrated science: A test of efficacy of a constructivist instructional strategy}

Igwebuike, Thomas B. $₫$

College of Education, Warri, Nigeria (dadaigwebuike@yahoo.com)

Oriaifo, Sylvester O.

University of Benin, Nigeria (sylvesteroriaifo@yahoo.com)

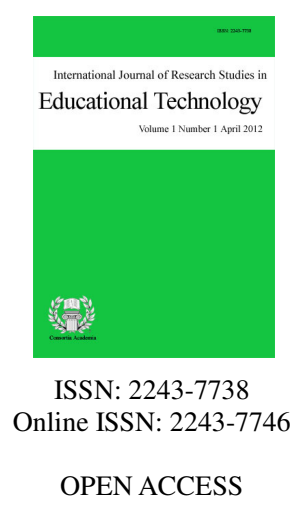

Accepted: 30 May 2012

\title{
Abstract
}

Results of several studies on the relationship between science students' perceptions of their classroom environments and their cognitive and affective achievements indicate strong association between the perceptions and the achievements. While this underscores the need for more effective relations in the classrooms, the issue of the effectiveness of some contemporary instructional strategies for teaching science in different classroom environments has not been addressed. This study, therefore, sought to find out if the constructivist instructional strategy can enhance cognitive and affective achievements of students in non-conducive environments. A total of 100 (57 boys, 43 girls) junior secondary two (grade 8) students participated in this experiment. Two instruments-the Cognitive Achievement Test and the Affective Achievement Test-were used in pre and post-test administration to measure the treatment effect on cognitive and affective achievements, respectively. Findings do not support the stand that the constructivist instructional strategy is more effective than the traditional (expository) teaching strategy for improving cognitive achievement. But with respect to affective achievement, the evidence supports the use of the constructivist strategy for instruction in non-conducive classroom environment. Implications of the study are discussed and recommendations given.

Keywords: constructivist strategy; classroom environment; achievement in Science; perceptions, psychosocial relations 


\section{Nature of classroom environment and achievement in integrated science: A test of efficacy of a constructivist instructional strategy}

\section{Introduction}

Several strands of evidence from studies converge to demonstrate that there is positive correlation between students' achievement in science and mathematics and their perceptions of their classroom environments (Haertel, Walberg, \& Haertel, 1981; Fraser \& Fisher, 1982; Wierstra, 1984; Walberg, 1984, 1986; Fraser, Walberg, Welch, \& Hattie 1987; Fraser, 1989; Fraser, Okebukola, \& Jegede, 1992; Akale \& Nwankwonta, 1996; Telli, Cakiroglu, \& den Brok, 2006; Okoh, 2011; Okonkwo, 2010). For instance, Haertel, Walberg, and Haertel (1981) carried out a meta-analysis involving 734 correlations from 12 studies involving 823 classes having a total of 17,805 students in four nations. Results of the studies indicated strong association between the students' perceptions and cognitive and affective measures. Following this exposition, the need to assist science and mathematics teachers to bring about practical improvements in the psychosocial relations in their classroom was highlighted (Fraser, 1981; 1989; Burden, 1991; Thorpe, Burden, \& Fraser, 1994; Igwebuike, 2000) have indicated positive results.

While studies are undertaken to improve psychosocial relations in science and mathematics classrooms, there is the need to relate the nature of classroom environment to contemporary instructional strategies. Literature is mute on the effect of instructional strategies on cognitive and affective achievements of students in various types of psychosocial learning environment. One of such strategies is constructivist instructional mode which is also referred to as conceptual pedagogy. Constructivist instructional strategy places much premium on students' prior knowledge which is also referred to as alternative framework or alternative conception. It is premised on an epistemology whose precepts, according to Driver and Bell (1986) and Driver and Oldham (1986), are:

$>\quad$ Individuals are purposive-learning does not take place by the learner responding in a passive way to the environment;

$>$ Prior knowledge matters a lot-learning depends not on the learning environment, but on what knowledge the learner brings to the learning situation;

$>\quad$ Knowledge is constructed by individuals through social interactions and experiences with physical environment; personal knowledge is constructed so as to "fit" with experiences in a coherent way,

$>$ Meaningful learning involves the construction of links with prior knowledge;

$>\quad$ Learning science involves conceptual change; it involves not only adding and extending one's conceptual structure but may involve radically reorganizing it.

Meaningful learning, according to the proponents of constructivism in science teaching, can take place when the learner's alternative conceptions are explored and used during instruction. The learner is assisted to examine the intelligibility, plausibility and fruitfulness of their conceptions in comparison with the scientific conceptions of study (Strike \& Posner, 1985) but within a learning situation that motivates the learner and respects his feelings (Pintrich, Marx, \& Boyle, 1993; Zhou, 2010; Igwebuike, 2011).

Constructivism, from the foregoing, provides a type of learning environment in which learners are actively involved in construction of meaning by making links with their alternative conceptions. Such an environment is a stark contrast to the traditional approach in which learners passively imbibe scientific concepts as presented by the teacher. There is ample research evidence to support the use of constructivism in science classrooms/ 
Nature of classroom environment and achievement in integrated Science

laboratories (Mitchell \& Baird, 1986; Trumper, 1990; 1991; Driver, 1990; Wheatley, 1991; Yager, 1991; Tobin, 1991; Gunstone, 1992; Cobern, 1996; Osborne, 1996; Asim, 1998; Bajah \& Asim, 2000; Chang \& Bell, 2002; Bell, 2005; Sjo berg, 2007; Ndioho, 2007; Benjamin \& Egho, 2008; Nwagbo, 2008). For example, Ndioho (2007) carried out a study on the effectiveness of a constructivist instructional model for teaching genetics to mixed-ability senior secondary school biology students (Grade 11). He found that the model was significantly more effective than the conventional expository method.

Since there is positive association between science students' perception of their learning environments and their achievement, students in conducive classroom environments will have better achievement. Non-conducive classroom environments, as mentioned earlier, have become the focus of intervention measures to make them conducive. This will promote effective science learning and achievement for students. Intervention measures can also be extended to include determination of the efficacy of constructivism in non-conducive classroom environments. It can be hypothesized that students in non-conducive classroom environments taught using constructivist instructional strategy will achieve significantly better in cognitive and affective learning in integrated science than their counterparts taught using the traditional expository strategy. Experimental evidence was sought in this study to test this proposition.

Specifically this study tested the following hypotheses:

1. There is no significant difference in cognitive achievement on energy concepts between students in non-conducive classroom environment taught using constructivist instructional strategy and their counterparts taught using traditional expository strategy.

2. There is no significant difference in affective achievement between students in non-conducive classroom environment taught using constructivist instructional strategy and their counterparts taught using traditional expository strategy.

\section{Method}

\subsection{Sample}

A total of 100 (57 boys 43 girls) junior secondary school (grade 8) students of Delta Career Secondary School and Step Forward Secondary School in Warri, Nigeria participated in this study. These schools were classified as non-conducive learning classroom environment. The categorization was carried out using the students' responses on Individualized Classroom Environment Questionnaire (to be described later). Two classes were randomly selected from each of the schools and each of the classes was intact to annul the effect of contamination which could confound the study. A second reason for using intact classes was to avoid disrupting normal instruction programs of the classes involved. Each of the two schools was randomly assigned to a treatment; either constructivist instructional strategy or traditional (expository) strategy. The subjects ranged in age from 12 years 8 months to 16 years 3 months with a mean of 14 years 3 months and a standard deviation of 0.72. All the subjects took integrated science as one of their courses preparatory to the junior secondary school certificate examinations.

\subsection{Instrumentation}

Four instruments were used for this study. They are: 1.) Cognitive Achievement Test; 2.) Affective Achievement Questionnaire; 3.) Individualized Classroom Environment Questionnaire; and 4.) Interview-about-Instances. The first two provided measures of the dependent variables of study while the last two were used for the manipulation of the independent variable.

Cognitive Achievement Test was used for measuring cognitive achievement based on energy concept referenced to the objectives of the instruction. The test had 30 multiple test items. Four sub-concepts of energy 
Igwebuike, T. B. \& Oriaifo, S. O.

were used for developing the lesson. They are: Energy as an Invention, Forms of energy, systems undergoing change, and conservation of Energy and they had 6, 8, 8 and 8 items respectively. The test had 35 items initially but based on the recommendations of a panel of 3 experts on integrated science teaching and 2 in measurement and evaluation, the items were reduced to 30 . Psychometric integrity of the test was determined using a pilot sample of 63 grade 8 students from a junior secondary school not used for the main study in two ways. The first is that the discriminatory power and difficulty indexes of the items were determined using suggestions by Mehrens and Lehman (1975). These measures were found to be within acceptable ranges. Specifically, the range with respect to the difficulty index was established at between 0.28 and 0.75 while the index of discriminatory power is between 0.31 and 0.65 while the recommended ranges are 0.25 to 0.75 and 0.30 to 0.48 respectively. The second is that the reliability coefficient was determined using Cronbach alpha. This exercise yielded a value of 0.75 which was considered adequate.

Affective Achievement Questionnaire designed and factorial validated by Afemikhe (1985) was used to measure affective components resulting from the use of constructivist instructional strategy. The instrument had 4 sub-scales of self-concept, confidence, attitude and motivation with 12,3,8 items respectively. The reliability coefficients of the items determined using Cronbach alpha were $0.65,0.59,0.46$ and 0.45 respectively.

Individualized Classroom Environment Questionnaire (ICEQ) was used to categorize environments into conducive and non-conducive types. The short from of the questionnaire was designed and developed by Fraser \& Fisher (1983). It has the following scales: Personalization, Participation, Independence, Investigation and Differentiation. Each of the scales has 5 items. The total number of items in ICEQ is 25. ICEQ was selected from several other similar instruments because of its simplicity and parsimony. These scales have reliability coefficients of $0.78,0.67,0.83,0.75$ and 0.78 respectively (Fraser \& Fisher, 1983). A cross-validation of ICEQ using a Nigerian sample produced test-retest reliability coefficient of 0.71 for personalization, 0.69 for participation, 0.76 for independence, 0.778 for investigation and 0.67 for differentiation, and a composite reliability coefficient of 0.73 . The determination of this last value was found necessary because all the scales were pooled together and used for dichotomizing classroom environments. A description of ICEQ is provided in Table 1.

\section{Table 1}

Description of ICEQ

\begin{tabular}{|c|c|c|}
\hline Scale Name & Scale Description & Sample Item \\
\hline Personalization & $\begin{array}{l}\text { Extent to which opportunities are provided for } \\
\text { individual student to interact with the teacher and } \\
\text { concern for the personal welfare of and social } \\
\text { growth of the individual. }\end{array}$ & $\begin{array}{l}\text { The teacher considers students' } \\
\text { feelings }(+)\end{array}$ \\
\hline Participation & $\begin{array}{l}\text { Extent to which students are allowed to make } \\
\text { decisions and have control over their own } \\
\text { learning and behavior }\end{array}$ & $\begin{array}{l}\text { The teacher lectures without } \\
\text { students asking or answering } \\
\text { questions (-) }\end{array}$ \\
\hline Independence & $\begin{array}{l}\text { Extent to which students are allowed to make } \\
\text { decisions and have control over their own } \\
\text { learning and behavior }\end{array}$ & $\begin{array}{l}\text { Students choose their partners for } \\
\text { group work }(+)\end{array}$ \\
\hline Investigation & $\begin{array}{l}\text { Emphasis on the skills and processes of inquiry } \\
\text { and their use in problem solving and } \\
\text { investigations }\end{array}$ & $\begin{array}{l}\text { Students find out the answers to } \\
\text { questions and problems from the } \\
\text { teacher rather than from } \\
\text { investigations (-) }\end{array}$ \\
\hline Differentiation & $\begin{array}{l}\text { Emphasis on selective treatment of students based } \\
\text { on ability, learning style, interests, and rate of } \\
\text { working }\end{array}$ & $\begin{array}{l}\text { Different students use different } \\
\text { books, equipment and materials } \\
(+)\end{array}$ \\
\hline
\end{tabular}


Interview-about-instances (IAI) designed and popularized by Osborne and Gilbert (1980a, 1980b) was used for probing the students' alternative conceptions. Instances of the sub-concepts were presented on different cards by means of line-drawings. Guides for the interview protocol suggested by the learning in Science Project of the University of Waikato, New Zealand were followed carefully. From the interviews (described under Design and Procedures), a catalogue of 17 students' alternative conceptions in the various sub-concepts developed was used during the instructional phase. The content coverage of the IAI cards was ascertained by the panel of 3 experts in integrated science teaching.

\subsection{Design and Procedure}

A non-equivalent control group design with random assignment of classes to experimental and control groups was employed to examine any possible treatment effect due to exposure to the constructivist instructional strategy. Experimental group was made up of subjects taught using this strategy while the control group had subjects who were taught using expository method. The two treatments shared a common curriculum content-energy. The Cognitive Achievement Test and the Affective Achievement Questionnaire were administered to all subjects as pre-tests. Interview-about-instances was organized for 15 randomly selected subjects in the experimental group using the cards with line-drawings of the sub-concepts. From this exercise, a catalogue of 17 alternative conceptions was made. These were compared with scientific conceptions and used as the basis for organizing constructivist instructional strategy.

To determine the nature of the classroom environment, ICEQ was administered to 50 randomly selected students from 4 randomly selected secondary schools in Warri Township, Nigeria. Based on the students' perceptions of their various classroom environments, two of the schools were categorized as non-conducive learning environment and used for this study. The other schools were not involved. The unit of analysis for this purpose was the individual student and not classrooms. This exercise was followed by eight weeks of instructional treatments. One of the researchers administered the treatments to control for the effect of some plausible teacher variables like skills-gap, commitment to the use of constructivist instructional strategy for teaching the experimental group, perceptions of classroom practices, and knowledge of the subject matter of study. Each group was taught for eight weeks with a total of twelve lessons of about 40 minutes per lesson.

Constructivist instructional strategy involved presenting relevant alternative conceptions, which have been catalogued, to the subjects in the experimental group. After this, the relevant scientific conceptions were presented and the subjects were assisted by the researcher/teacher to assess the usefulness and plausibility of their conceptions. Value was placed on students; conceptions by the researcher/teacher. The students' feelings and interests were respected as a way of motivating them for dialogue/negotiations. Because of the observation by Lawson and Thompson (1988) that students at the concrete operational level find it difficult to evaluate competing theories, guides were given to the subjects in the experimental group for analyzing the implications of both their conceptions and scientific conceptions. Subjects in the control group were not involved with the interviews. They were taught using the expository approach. After eight weeks of instruction, the two groups were given both the posttests on cognitive and affective achievements. These tests were administered in the same manner as the pretests.

\section{Results}

A t-test analysis was carried out to ascertain or not if the difference between the perceptions of students in conducive and non-conducive learning environment achieved significance. This was to guarantee adequate polarization of the two sets of schools. The results indicated that the difference is significant $[\mathrm{t}(198)=3.06$, $p<0.05]$. The label of non-conducive learning environment was therefore justified by empirical evidence. Similarly, the results of t-tests carried out to determine if the experimental and control groups were equivalent with respect to cognitive and affective achievements indicated that there were initial differences $[\mathrm{t}(98)=4.55$, $p<0.05]$ and [t(98) $=2.34, p<0.05]$ respectively. Analysis of covariance (ANCOVA) was used since it can adjust 
Igwebuike, T. B. \& Oriaifo, S. O.

for initial difference in measures of the dependent variables.

The aim of this study was to investigate whether instruction using constructivist instructional strategy had any significant effect on cognitive and affective achievements of integrated science students in non-conducive psychosocial classroom environment.

Table 2

Descriptive statistics of Pre-test Cognitive and Affective Scores according to group

\begin{tabular}{llccc}
\hline Measure of Comparison & \multicolumn{1}{c}{ Group } & $N$ & Mean & $S D$ \\
\hline Cognitive & Experimental & 50 & 4.49 & 1.40 \\
& Control & 50 & 3.08 & 1.64 \\
Affective & Experimental & 50 & 54.20 & 8.15 \\
& Control & 50 & 48.17 & 8.47 \\
\hline
\end{tabular}

Table 3

Descriptive statistics of Post-test Cognitive and Affective Scores according to groups

\begin{tabular}{llllc}
\hline Measure of Comparison & \multicolumn{1}{c}{ Group } & $N$ & Mean & $S D$ \\
\hline Cognitive & Experimental & 50 & 13.58 & 1.68 \\
& Control & 50 & 12.32 & 1.52 \\
Affective & Experimental & 50 & 56.22 & 8.44 \\
& Control & 50 & 51.30 & 8.32 \\
\hline
\end{tabular}

Table 4

ANCOVA summary of Cognitive Achievement Test Post-test scores

\begin{tabular}{lrrrc}
\hline \multicolumn{1}{c}{ Source } & \multicolumn{1}{c}{$S S$} & $D F$ & \multicolumn{1}{c}{$M S$} & \multicolumn{1}{c}{ F } \\
\hline Covariates & 441.521 & 1 & 441.521 & 26.52 \\
Method & 44.045 & 1 & 44.045 & 2.64 (NS) \\
Explained & 485.566 & 2 & 242.783 & 14.58 \\
Residual & 1614.434 & 97 & 16.644 & \\
\hline Total & 2100.000 & 99 & 21.212 & \\
\hline
\end{tabular}

Note. $\mathrm{NS}=$ not significant

Results in table 4 indicate that constructivist instructional strategy did not significantly improve cognitive achievement by subjects in non-conducive psychosocial classrooms $[\mathrm{F}(1,97)=2.646, p>0.05$. Multiple classification analysis carried out indicated that the subjects in the experimental group had an adjusted post-test cognitive achievement mean score of 13.58 while those in the control group had and adjusted post-test mean score of 13.22. Comparison of the post-test scores of the two groups on affective achievement did show a significance as revealed by results displayed in Table $6[\mathrm{~F}(1,97)=42.577, p<0.05]$. Multiple classification analysis carried out indicated that the subjects in non-conducive psychosocial environment exposed to constructivist instructional strategy (experimental group) had an adjusted mean score of 56.22 while their counterparts exposed to the traditional method had an adjusted mean score of 51.30. Constructivist instructional strategy did improve affective achievement significantly.

\section{Discussion of results}

The study set out to investigate if the constructivist instructional strategy can improve integrated science students' cognitive and affective achievements. The results obtained (see Table 4) suggest that the constructivist 
Nature of classroom environment and achievement in integrated Science

instructional strategy did not improve cognitive achievement of students of integrated science in non-conducive learning environment significantly $[\mathrm{F}(1,97)=2.646, p>0.05]$. Secondly, the strategy significantly improved affective achievement $[\mathrm{F}(1,97)=42.577, p<0.05]$ (see Table 6$)$.

\section{Table 5}

Multiple classification analysis of covariance of Post-test Cognitive Achievement

\begin{tabular}{|c|c|c|c|c|c|}
\hline $\begin{array}{l}\text { Grand Mean }=13.40 \\
\text { Variables + Category }\end{array}$ & $N$ & $\begin{array}{l}\text { Unadjusted } \\
\text { Deviation }\end{array}$ & ETA & $\begin{array}{l}\text { Adjusted for } \\
\text { Independents + Covariance } \\
\text { Deviation }\end{array}$ & BETA \\
\hline \multicolumn{6}{|l|}{ Method } \\
\hline 1. Constructivist Strategy & 50 & 0.18 & & -0.72 & \\
\hline \multirow[t]{2}{*}{ 2. Traditional Method } & 50 & -0.08 & & 0.72 & \\
\hline & & & 0.04 & & 0.16 \\
\hline Multiple R. Squared & & & & & 0.231 \\
\hline Multiple R & & & & & 0.481 \\
\hline
\end{tabular}

Table 6

ANCOVA summary of Affective Achievement Test Post-test scores

\begin{tabular}{lrrrr}
\hline \multicolumn{1}{c}{ Source } & \multicolumn{1}{c}{$S S$} & $D F$ & \multicolumn{1}{c}{$M S$} & F \\
\hline Covariates & 5878.032 & 1 & 5878.032 & 481.420 \\
Method & 519.860 & 1 & 519.860 & $42.577^{*}$ \\
Explained & 6397.892 & 2 & 3198.946 & 261.999 \\
Residual & 1184.348 & 97 & 12.210 & \\
Total & 7582.240 & 99 & 76.599 & \\
\hline
\end{tabular}

Note. *significant at $p<0.05$

Table 7

Multiple classification analysis of the covariance of Post-test Affective Achievement

\begin{tabular}{lcccc}
\hline $\begin{array}{c}\text { Grand Mean = 53.76 } \\
\text { Variables + Category }\end{array}$ & $N \quad \begin{array}{l}\text { Unadjusted } \\
\text { Deviation }\end{array}$ & $\begin{array}{l}\text { Adjusted for } \\
\text { ETA } \\
\text { Independents + Covariance } \\
\text { Deviation }\end{array}$ & BETA \\
\hline $\begin{array}{l}\text { Method } \\
\text { 3. Constructivist Strategy }\end{array}$ & 50 & 2.46 & 2.28 & 0.26 \\
4. Traditional Method & 50 & -2.46 & -2.28 & 0.841 \\
& & & & \\
Multiple R. Squared & & & & 0.918 \\
Multiple R & & & & \\
\hline
\end{tabular}

With regards to cognitive achievement, the results obtained in this study were unexpected and they indicated stark contrasts to earlier findings of Zietsman and Hewson (1986); Trumper (1990, 1991); Asim (1989); Bajah \& Asim (2000); Ndioho (2007). Constructivist instructional strategy seems to possess characteristics that can enhance meaningful learning of science (Benjamin \& Egho, 2008). For instance, it provides a learning environment in which students are actively involved in construction of knowledge. It also provides an affective social environment for negotiations between students and teachers about alternative conceptions and scientific conceptions. There is the possibility of the individual learners generating their own understanding of the 
concepts being studied in the class. It is surprising, from the foregoing, that the strategy did not significantly improve cognitive achievement in this study. However, the results of this study, with reference to cognitive achievement, are supported by findings of studies carried out by Chang (2000) and Chang \& Bell (2002).

Two factors, speculatively, have influenced the result obtained in this study. The first is the novelty provided by the constructivist instructional strategy. Within this type of learning situation, students' alternative conceptions are valued and used for instructional purposes. The teacher respects the students' conceptions and makes himself a part of the problem-solving group. This type of learning situation, seemingly, from the students' point of view, would not be for examination or test purposes as the expository strategy. The guess therefore, is that the posttest did not elicit adequate responses from the subjects taught using the constructivist strategy. The second factor is sourced from the nature of the cognitive posttest used in this study. It consisted of a number of multiple-choice items. If interview-about-instances, which is one of the features of the constructivist strategy, was built into the achievement posttest subtly, the results may be different.

With regards to affective achievement, the enhanced learning by integrated science students in non-conducive environment achieved through the constructivist instructional strategy, as revealed in this study, is in agreement with the characteristics of the strategy outlined earlier. It should be noted that the strategy provides a learning situation which places value on their alternative conceptions and helps them to assess their plausibility and fruitfulness (Strike \& Posner, 1985) vis-à-vis the scientific conceptions of study. In this case, students participate actively and collaboratively during lessons. There are negotiations (Jegede \& Taylor, 1998; Zhou, 2010; Igwebuike, 2011) during such assessments instead of impositions of corpus of scientific knowledge which characterize teacher-dominated expository lessons. It is not surprising, from the foregoing, that the constructivist strategy boosted students' self-concept, science confidence, attitudes and motivation, which among others, constitute the affect.

In this direction, the results of this study are interesting. West \& Pines (1983) argue that while it is important to create situations which will challenge students' alternative conceptions to bring about conceptual shift, their feelings and dispositions are an important aspect of the process. They say that the learner should feel good, or proud, or satisfied after conceptual change or constructivist instructional strategy has been used. The learner should not feel bad, demeaned or dissatisfied. They are further supported by Pintrich, Marx and Boyle (1993), Zhou, (2010), Igwebuike, (2011). Studies by Chang (2000) and Chang \& Bell (2002), Ndioho (2007) provide evidence in support of the findings of this study. They found that the use of constructivist instructional strategy improved students' perceptions of interest, satisfaction, enjoyment and achievement; willingness to attend, listen to the lesson and participate in discussions; and increased learning commitment out of class.

The positive results obtained in the affective area of this study are heart-warming. This is mainly because of the strong association between affective components and cognitive achievement (Byrne, 1984; Iran-Nahed, 1987; Aghadiuno, 1992; Ukwungwu \& Nworgu, 1999). The association suggests the possibility of improving cognitive achievement, through the use of the constructivist instructional strategy, for students in non-conducive environments. A major implication of this study for science teaching is that science teachers, as well as teacher educators, should recognize the likely effect of the constructivist instructional strategy on affective achievement for students in non-conducive classroom environments. A major goal of teaching science is the development of the affective components. This study suggests that this strategy is effective for realizing this goal. While studies are carried out to assist science teachers to improve psychosocial relations in their classrooms, the constructivist instructional strategy may be used for teaching integrated science in non-conducive classroom environments.

This study should be replicated because of three reasons. The first is that the design used in the study does not provide strict control and as a result, probable effects of some confounding variables may impair external validity. The second is that the study is a single-variable (independent) study. Walberg (1970) suggests that each of the predictor variables of learning outcomes may be necessary but insufficient by itself for classroom learning to occur. A study that will increase the number of independent variables and determine their interactive 
effects is therefore strongly advocated. The third is that the results of the study with reference to cognitive achievement suggest a design of study that will incorporate triangulation. It is considered auspicious to suggest that this phenomenon is studied using a combination of assorted techniques as is recommended by triangulation. By implication, cautious interpretation and application of the conclusions of this study to integrated science teaching are encouraged. Nevertheless, our findings suggest the validity and desirability of the general direction of enquiry attempted in this study.

\section{Conclusion}

The results obtained from this study support the conclusion that constructivist instructional strategy does not improve cognitive achievement among integrated science in non-conducive classroom environments. But the results strengthen the conclusion that the strategy improves achievement among this category of students. Since research evidence has established strong association between affective and cognitive achievements, the strategy can be explored further for use in teaching integrated science to students in non-conducive classroom environment.

\section{References:}

Afemikhe, O. A. (1985). The effect of formative testing on students' achievement in secondary mathematics. Unpublished PhD Dissertation, University of Ibadan, Nigeria.

Aghadiuno, M. C. (1992). A path-analysis study of cognitive style, understanding of science and attitudinal variables as correlates of achievement in secondary school chemistry. Unpublished PhD Dissertation, University of Ibadan, Nigeria.

Akale, M. A., \& Nwankwonta, N. A. (1996). A study of students' and teachers' perceptions of laboratory/classroom environments in senior secondary schools. Journal of the Science Teachers' Association of Nigeria, 31(1 \& 2), 13-20.

Asim, A. E. (1998). An evaluation of the relative effectiveness of two interactive approaches based on the constructivist perspective for teaching primary science. Unpublished PhD Dissertation, University of Ibadan, Nigeria.

Bell, B. (2000). Formative assessment and science education: Modeling and theorizing. In R. Millar, J. Leach and J. Osborne (eds.). Improving science education: The contribution of research. Buckingham: Open University Press.

Bell, B. (2005). Pedagogies developed in the learning in Science projects and related theses. International Journal of Science Education, 27(2), 159-182. <http://dx.doi.org/10.1080/0950069042000276703>

Benjamin, A., \& Egho, E. (2008). Constructivism: A paradigm for effective classroom practice. Agbor Journal of Science Education, 3(1), 265-277.

Burden, R. L. (1991). Assessing and improving classroom learning environments. In G. Lindsay \& A. Miller (eds.). Psychological services for primary schools. New York: Longman.

Byrne, M. (1984). The general/academic self-concept nomological network: A review of construct validation research. Review of Educational Research, 54, 427-456.

Chan, K. W. (2001). Validation of a measure of personal theories about teaching and learning. Paper presented in the AARE Annual Conference held at Fremantle, Perth, Australia.

Chan, K. W. (2007). Hong Kong teacher education students' epistemological beliefs and their relations with conceptions of learning and teaching strategies. The Asia-Pacific Education Researcher, 16, 199-214.

Chang, W., \& Bell, B. (2002). Making content easier or adding more challenge in year one university physics. Research in Science Education, 32(1), 81-96. <http://dx.doi.org/10.1023/A:1015054804515>

Chang, W. (2000). Improving teaching and learning of university physics in Taiwan. Unpublished $\mathrm{PhD}$ Dissertation, University of Waikato, Hamilton.

Cobern, W. W. (1996). Constructivism and non-western science education research. International Journal of Science Education, 4(3), 287-302. 
Igwebuike, T. B. \& Oriaifo, S. O.

Driver, R., \& Bell, B. (1986). Students' thinking and the learning of science. A constructivist view. The School Science Review, 67(24), 443-456.

Driver, R., \& Oldham, V. (1986). A constructivist approach to curriculum development in science education. Studies in Science Education, 12, 105-122. <http://dx.doi.org/10.1080/03057268608559933>

Driver, R. (1990). The teaching and understanding of concepts in science. In N. Entwistle (ed.), The international encyclopedia of education (vol. 2). England: Pergamamon Press.

Fraser, B. J., \& Fisher, D. L. (1982). Predicting students' outcomes from their perceptions of classroom environment. American Educational Research Journal, 19, 498-518.

Fraser, B. J., \& Fisher, D. L. (1983). Development and validation of short forms of some instruments for measuring students' perceptions of actual and preferred classroom learning environment. Science Education, 67, 115-131. <http://dx.doi.org/10.1002/sce.3730670114>

Fraser, B. J. (1989). Twenty years of classroom climate work: Progress and prospect. Journal of Curriculum Studies, 21(4), 207-327. <http://dx.doi.org/10.1080/0022027890210402>

Fraser, B. J., Okebukola, P. A., \& Jegede, O. J. (1992). Assessment of the learning environment of Nigerian science laboratory/classrooms. Journal of the Science Teachers' Association of Nigeria, 27(2), 1-17.

Fraser, B. J., Walberg, H. J., Welch, W. W., \& Hattie, J. A. (1987). Synthesis of educational productivity research. International Journal of Educational Research, 11, 145-252. $<$ http://dx.doi.org/10.1016/0883-0355(87)90035-8>

Gunstone, R. I. (1992). Constructivism and meta-cognition: Theoretical issues and classroom studies. In R. Duit, I. Goldberg, \& H. Niedderer (eds.), Research in physics learning: Theoretical issues and empirical studies. Kiel-Germany: IPN.

Igwebuike, T. B. (2000). Effects of constructivist instructional strategy on students' achievement in integrated science. Unpublished PhD Dissertation, University of Benin, Nigeria.

Igwebuike, T. B. (2010). The effect of conceptual change pedagogy on learning outcomes on energy concepts by low achievers in integrated science. A research paper, College of Education, Warri, Nigeria.

Igwebuike, T. B. (2011). Epistemic motivation for conceptual change pedagogy in integrated science classrooms in non-western cultures. A research paper, College of Education, Warri, Nigeria.

Iran-Najed, A. (1987). Cognitive and affective causes of interest and liking. Journal of Educational Psychology, 79(2), 120-130. <http://dx.doi.org/10.1037/0022-0663.79.2.120>

Jegede, O. J., \& Taylor, P. C. (1998). The role of negotiation in a constructivist-oriented hands-on and minds on science laboratory classroom. Journal of the Science Teachers' Association of Nigeria, 33(1 \& 2), 88-98.

Lawson, A. E., \& Thompson, I. D. (1988). Formal reasoning ability and biological misconceptions concerning genetics and natural selection. Journal of Research in Science Teaching, 25, 733-746. $<$ http://dx.doi.org/10.1002/tea.3660250904>

Mehrens, W. A., \& Lehmann, I. J. (1975). Measurement and evaluation in education and psychology. New York: Holt, Rinehart \& Winston.

Mitchel, I., \& Baird, J. (1986). Teaching, learning and curriculum: The influence of content in science. Research in Science Education, 16, 135-140. <http://dx.doi.org/10.1007/BF02356828>

Ndioho, O. F. (2007). Effect of constructivist-based instructional model on senior secondary students achievement in biology. In U. Nzewi (ed.) Science, technology and mathematics education for sustainable development (pp. 98-101). Ibadan, Nigeria: Heinemann Educational Books Nigeria.

Nwagbo, C. (2008). Science, Technology and Mathematics Curriculum Development: Focus on problems and prospects of biology curriculum delivery. In N. Udofia (ed.) Curriculum development in science technology and mathematics education (pp. 77-81). Ibadan, Nigeria: Heinemann Educational Books Nigeria.

Okoh, A. S. (2011). Comparison between perceptions of classroom environment by biology students in public and private secondary schools. PGDE Project, University of Port Harcourt, Nigeria.

Okonkwo, C. (2010). Relationship between secondary school students' perceptions of classroom learning environment and their achievement in chemistry. PGDE Project, University of Port Harcourt, Nigeria. 
Osborn, F. (1996). Beyond constructivism. Science Education, 80(1), 53-82. $<$ http://dx.doi.org/10.1002/(SICI)1098-237X(199601)80:1<53::AID-SCE4>3.0.CO;2-1>

Osborne, R. J., \& Gilbert, J. K. (1980). A technique for exploring students' views of the world. Physics Education, 15, 376-379. <http://dx.doi.org/10.1088/0031-9120/15/6/312>

Pintrich, P. R., Marx, R. W., \& Boyle, R. A. (1993). Beyond cold conceptual change: The role of motivational beliefs and classroom contextual factors in the process of conceptual change. Review of Educational Research, 63(2), 167-199.

Sjo berg, S. (2007). Constructivism and learning. In E. Baker, B. McGraw, \& P. Peterson (eds.), International encyclopedia of education (3rd ed.). Oxford: Elsevier.

Strike, K., \& Posner, G. J. (1985). A conceptual change view of learning and understanding. In L. H. T. West \& A. L. Pines (eds.), Cognitive structure and conceptual change. New York: Academic Press.

Telli, S., Cakiroglu, J., \& den Brok, P. (2006). Turkish secondary education students' perceptions of their classroom learning environment and their attitude towards Biology. In D. C. Fisher \& M. S. Khine (eds.), Contemporary approaches to research on learning environments: World views (pp. 517-542). Singapore: World Scientific. <http://dx.doi.org/10.1142/9789812774651_0022>

Thorpe, H. S., Burden, R. L., \& Fraser, B. J. (1994). Assessing and improving classroom environment. School Science Review, 75, 107-113.

Tobin, K. G. (1991). Constructivist perspectives on research in science education. A paper presented at the Annual meeting of the National Association for Research in Science Teaching, Geneva.

Trumper, R. (1990). Being constructive: An alternative approach to the teaching of the energy concept Part I. International Journal of Science Education, 12(4), 411-436. <http://dx.doi.org/10.1080/0950069900120402>

Trumper, R. (1991). Being constructive: An alternative approach to the teaching of the energy concept Part II. International Journal of Science Education, 13(2), 142-160.

Walberg, H. J. (1970). A model for research on instruction. School Review, 78, 185-200. $<$ http://dx.doi.org/10.1086/442899>

Walberg, H. J. (1984). Improving the productivity of America's schools. Educational Leadership, 41, 19-30.

Walberg, H. J. (1986). Synthesis of research on teaching. In M. C. Wittrock (ed.), Handbook of Research on Teaching (3rd ed.). Washington: American Educational Research Association.

West, L. H., \& Pines, A. L. (1983). How rational is rationality? Science Education, 67(1), 37-39. $<$ http://dx.doi.org/10.1002/sce.3730670106>

Wheatley, G. H. (1991). Constructivist perspectives on science and mathematics learning. Science Education, 75(1), 9 - 21. <http://dx.doi.org/10.1002/sce.3730750103>

Wierstra, R. (1984). A study on classroom environment and on cognitive and affective outcomes of the PLON-curriculum. Studies in Educational Evaluation, 10, 273-282.

Yager, R. E. (1991). The constructivist learning model. The Science Teacher, 52-57.

Zhou, G. (2010). Conceptual change in science: A process of argumentation Eurasia Journal of Mathematics, Science \& Technology Education, 6(2), 101-110.

Zietsman, A. I., \& Hewson, P. W. (1986). Effect of instruction using micro-computer simulations and conceptual change strategy on science learning. Journal of Research in Science Teaching, 23 (1), 27-39. $<$ http://dx.doi.org/10.1002/tea.3660230104> 


\section{Appendix 1}

Sample items from cognitive achievement test

Instructions: Try to answer all questions and work as carefully as you can. Each question has four alternative answers. Only one of them is correct. Decide which one is correct and circle it.

1. Energy is
(a) a concrete object
(b) something that moves
(c) something that is invented to help us study changes in objects
(d) cooking gas

2. Fuel, e.g. kerosene, is
(a) energy
(b) energy resource
(c) heavier than water
(d) always used up

3. Energy in crude oil comes from the
(a) soil
(b) sea
(c) sun
(d) oil companies

4. A bulb connected to a battery lights because
(a) electrical energy is converted into light energy
(b) heat energy is converted into light energy
(c) mechanical energy is converted into light energy
(d) kinetic energy is converted into light energy

5. On a sunny day, metal roof of a building makes creaky sound because the metal sheet
(a) is contracting
(b) is stronger
(c) is expanding
(d) is becoming thicker

6. An ice block removed from a freezer melts because it
(a) contains water
(b) gains energy from the surrounding
(c) is small in size
(d) loses energy to the surrounding 


\section{Appendix 2}

Sample items in the affective achievement test

\begin{tabular}{|c|c|c|c|c|c|c|}
\hline & Scale Name & & Sample items & 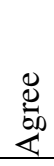 & $\begin{array}{l}\bar{d} \\
\frac{d}{0} \\
\frac{d}{0} \\
\underline{D}\end{array}$ & 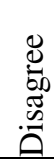 \\
\hline \multirow[t]{2}{*}{1.} & Self-concept & 1. & Science is easier for me than most school subjects & & & \\
\hline & & & $\begin{array}{l}\text { The more important the science tests, the less well I } \\
\text { seem to do. }\end{array}$ & & & \\
\hline 2. & Confidence & 1. & I think I am doing well in the school science & & & \\
\hline \multirow[t]{2}{*}{3.} & Attitude & 1. & The subject that I enjoy least is science & & & \\
\hline & & 2. & Science is fun & & & \\
\hline 4. & Motivation & & $\begin{array}{l}\text { There is so much hard work in science that it takes the } \\
\text { enjoyment out of it. }\end{array}$ & & & \\
\hline & & 2. & No matter how hard I try, I cannot understand science. & & & \\
\hline
\end{tabular}


Igwebuike, T. B. \& Oriaifo, S. O. 